\title{
E-Commerce Solusi Pemasaran UMKM Dalam Mengembangkan Industri Pariwisata Di Tengah Pademi Covid-19 (Studi Kasus Umkm Di Kota Tasikmalaya)
}

\author{
Yani Sri Mulyani \\ Prodi Sistem Informasi, Fakultas Tekhnik Informatika, \\ Universitas Bina Sarana Informatika \\ Jalan Tanuwijaya No 4 Empang Sari Tawang Kota Tasikmalaya \\ Email : yani.ymn@bsi.ac.id
}

\begin{abstract}
Abstrak
E-commerce merupakan solusi bagi pelaku usaha mikro, kecil serta menengah dalam menjalankan bisnisnya di tengah pademi covid-19 karena UMKM merupakan sektor ekonomi kreatif yang terserang dampaknya. Tujuan dari riset ini adalah untuk mengetahui bahwa peranan E-commerce sangatlah mendukung bagi kelangsungan hidup bisnis pelaku UMKM dan dalam mengembangkan industri pariwisata di Tasikmalaya .Populasi atau sample yang diambil sebanyak 10 UMKM yang ada di Tasikmalaya yang tersebar di Kota dan Kabupaten Tasikmalaya dengan beragam jenis usaha bisnisnya. Metode yang dipakai adalah kualitatif deskritif dimana peneliti mewawancarai pemilik UMKM melalui media sosial dikarenakan maasih pemberlakuan pembatasan kegiatan masyarakat (PPKM) sehingga tidak memungkinkan untuk mewawancarai pemilik UMKM secara langsung. metode penelitian ini dihitung berapa presentase penjualan yang didapat pelaku UMKM. Hasil dari penelitian selama bulan Mei sampai dengan bulan Oktober 2020 bahwa presentasi dapat dilihat meningkat dibulan Juni $11,3 \%$ sd 21,2\% ,rata-rata menurun di bulan Juli sd Agustus 9,5\% s.d 15,6\% dari bulan September ke Oktober dan rata-rata naiknya diangka $15 \%$ sd $42,5 \%$. Hal ini menunjukan bahwa $E$ commerce menjadi solusi bagi pelaku UMKM ditengah masa pademi covid-19 dan merupakan upaya untuk mengembangkan industri pariwisata. Hal itu dapat mengurangi budget pemasaran yang mana kemudahan dan kecanggihan tekhnologi dalam menyampaikan informasi tentang barang dan jasa yang langsung dialamatkan ke tangan konsumen.Sehingga komsumen atau pembeli tinggal memesan dari rumah dan barang langsung diantar ke rumah sesuai pesanan.
\end{abstract}

Kata kunci: E-commerce, UMKM, Pademi Covid 19, industri pariwisata

\begin{abstract}
E-commerce is a solution for micro, small and medium businesses in running their business in the midst of the COVID-19 pandemic because MSMEs are one of the creative economic sectors that have been affected. The purpose of this study is to find out that the role of E-commerce is very supportive for the survival of MSME business actors and in developing the tourism industry in Tasikmalaya. The population or sample taken is 10 MSMEs in Tasikmalaya which are spread in the City and District of Tasikmalaya with various types of businesses. his business. The method used is descriptive qualitative where researchers interview MSME owners through social media because there are still restrictions on community activities (PPKM) so it is not possible to interview MSME owners directly. This research method calculates the percentage of sales obtained by MSME actors. The results of the research during May to October 2020 that the presentation can be seen increasing in June $11.3 \%$ to $21.2 \%$, the average decreased in July to August 9.5\% to $15.6 \%$ from September to October and the average increase was $15 \%$ to $42.5 \%$. This shows that E-commerce is a solution for MSME players in the midst of the COVID-19 pandemic and is an effort to develop the tourism industry. This can reduce the marketing budget where the ease and sophistication of technology in conveying information about goods and services are directly addressed to consumers.
\end{abstract}

Keywords: E-commerce,UMKM, Covid 19 pandemic, tourism industry. 


\section{PENDAHULUAN}

Pemeritah menetapkan wabah virus corona( Covid- 19) selaku Musibah Alam Nasional lewat Keputusan Presiden No 12 Tahun 2020 Penetapan Musibah Non alam Penyebaran Covid- 19 Selaku Musibah Nasional.(Putri, 2020)" Semenjak World Health Organization menetapkan kalau Covid- 19 merupakan pandemi, semenjak itu pula negara- negara dibelahan dunia dihantui kecemasan. Pandemi sendiri mempuyai penafsiran suatu Epidemi yang sudah menyebar ke sebagian negeri ataupun daratan, serta biasanya banyak menjangkiti banyak orang".

Epidemi ialah sebutan yang kerap kita dengar buat kenaikan jumlah permasalahan penyakit secara seketika pada populasi wilayah tertentu. Dikala ini Indonesia sudah jadi salah satu negeri Pandemi apalagi mengarah Epidemi. Indonesia yang semula dikenal warganya terkena akibat terkontaminasi virus dari negeri lain, dikala ini sudah mengarah penularan berskala lokal.Menurut (Putri, 2020)“ Semenjak terbentuknya wabah Corona, pasti saja perihal ini berakibat pada energi beli dari warga itu sendiri. Semacam yang kita tahu kalau bisnis UMKM jadi salah satu zona yang sangat merasakan akibat wabah Virus Corona( Covid19). Bersumber pada kabar dari Departemen Koperasi serta UKM ( Kemenkop UKM) paling tidak ada 949 laporan dari pelakon koperasi dan usaha mikro, kecil, serta menengah( UMKM) yang terserang akibat wabah virus Corona( Covid- 19)."

Seperti yang disinyalir oleh (Reswari, 2020) bahwa " yang membuat penjualan UMKM mengalami penurunan. Sebanyak 774 koperasi dan UMKM atau setara dengan $68 \%$ mengaku bahwa penjualan mereka mengalami penurunan drastis sejak wabah Virus Corona. Penurunan ini pun turut dirasakan di berbagai kota di Indonesia, seperti DKI Jakarta, Jawa Barat, Banten, Jawa Tengah, Jawa TImur, Yogyakarta, Sumatera Barat, Sumatera Utara, Bengkulu, Riau, Kalimantan Barat, Kalimantan Timur, Kalimantan Selatan, Bali, Sulawesi Tengah, Sulawesi Selatan, hingga Sulawesi Utara".

Pelaku usaha/UMKM memanfaatkan masa ini untuk meningkatkan keahlian yang dimiliki demi perkembangan bisnis kedepannya. Keahlian yang dimiliki mereka di bidang pemasaran via digital atau mengembangkan platform e-commerce. Ketika bisnis berjalan dengan normal, operasional bisnis dapat dijalankan lebih cepat dari sebelumnya.

Menurut .(Dinisari, 2010) dalam artikel nya bahwa "E-commerce pada dasar nya sudah mampu menarik banyak konsumen di Indonesia bahkan sebelum terjadinya wabah Covid-19. E-commerce juga merupakan salah satu pendorong utama yang menjadikan Indonesia sebagai negara dengan nilai ekonomi digital terbesar di Asia Tenggara mencapai $\$ 40$ miliar pada tahun 2019 dan diprediksi meningkat hingga $\$ 130$ miliar pada tahun 2025"

Penelitian ini bertujuan untuk mengetahui Bahwa e-commerce merupakan solusi penjualan bagi pengusaha UMKM serta upaya untuk mengembangkan industri pariwisata di tengah masa pademi covid19.Sehingga pembeli bisa membeli barang yang diinginkannya tampa harus keluar rumah.

\section{KAJIAN PUSTAKA}

\section{E-Commerce}

Secara umum pengertian dari $E$ commerce diambil dari bahasa Inggris yaitu Electronic Commerce atau perdagangan elektronik .Menurut (Kotlerand \& Armstrong, 2012) "E-commerce adalah saluran online yang dapat dijangkau seseorang melalui komputer, yang digunakan oleh pebisnis dalam melakukan aktifitas bisnisnya dan digunakan konsumen untuk mendapatkan informasi dengan menggunakan bantuan komputer yang dalam prosesnya diawali dengan memberi jasa informasi pada konsumen dalam penentuan pilihan."

Menurut (Wong, 2010) bahwa "ecommerce adalah proses jual beli dan memasarkan barang serta jasa melalui sistem elektronik, seperti radio, televisi dan jaringan komputer atau internet." Berikut ini terdapat empat jenis e-commerce berdasarkan karasteristiknya menurut (Kotler and Armstrong, 2012): (1) Business to business (B2B); (2) Business to consumer (B2C); (3) Consumer to Consumer (C2C); (4) Consumer to Business (C2B).

Hal ini disimpulkan bahwa e-commerce adalah kumpulan dinamis antara teknologi, aplikasi dan proses bisnis yang 
menghubungkan perusahaan dan konsumen serta komunitas tertentu dimana pertukaran barang antara pengecer dan konsumen dari berbagai komoditi dalam skala luas dan suatu transaksi elektronik, dan dalam proses pengiriman barang dari pengecer menggunakan transportasi dari suatu wilayah ke wilayah lain hingga sampai ke tangan konsumen dan hubungan yang terjadi adalah hubungan yang saling menguntungkan kedua belah pihak.

\section{Pemasaran}

Sejak berakhirnya perang kedua, pemasaran telah muncul sebagai salah satu disiplin utama dalam manajemen bisnis modern. Hali ini bisa dilihat sebagai power house dari kemakmuran pertumbuhan industri yang kita capai selama periode ini:

Menurut (Kotler Philip and Armstrong Gary, 2016) Philip bahwa : "marketing as he science and art of exploring, creating, and delivering value to satisfy the needs of a target market at a profit. Marketing identifies unfulfilled needs and desires.It defines, measures and quantifies the size of the dentified market and the profit potential. It pinpoints which segments the company is capable of serving best and it designs and promotes the appropriate products and services." Hali ini bisa disimpulkan bahwa: (1) pemasaran dalam pengertian kegiatan usaha adalah memindahkan barang dan jasa dari produsen ke konsumen atau pengguna; (2) Pengertian fungsi pemasaran dalam hal ini sebagai jembatan antara produsen dan konsumen; (3) c.Pemasaran merupakan komitmen perusahaan total di mana setiap orang terlibat; (4) d. Pemasaran merupakan aktivitas manusia yang terjadi dan ada kaitannya dengan pasar; (5) Pemasaran juga bisa diartikan bekerja dengan markets untuk mengaktualisasikan pertukaran potensial untuk tujuan memuaskan kebutuhan dan keinginan manusia.

\section{Usaha Mikro Kecil dan Menengah (UMKM)}

Usaha mikro kecil dan menengah atau bisa disingkat UMKM.Menurut (UndangUndang Republik Indonesia Tentang Usaha Mikro, Kecil, Dan Menengah, 2008a) bahwa definisi UMKM adalah "usaha perdagangan yang dikelola oleh badan usaha atau perorangan yang merujuk pada usaha ekonomi produktif sesuai dengan kriteria yang ditetapkan."Seperti yang ditetapkan. (Undang-
Undang Republik Indonesia Tentang Usaha Mikro, Kecil, Dan Menengah, 2008a) ada beberapa kriteria yang digunakan yaitu :

Usaha Mikro, Usaha produktif milik perseorangan dan/atau badan usaha perseorangan yang memenuhi kriteria usaha mikro yang diatur dalam undang-undang.

Usaha Kecil, Usaha ekonomi produktif yang berdiri sendiri dan dilakukan oleh perseorangan atau badan usaha yang bukan merupakan anak perusahaan atau bukan cabang perusahaan yang dimiliki, dikuasai, atau menjadi bagian baik langsung maupun tidak langsung dari usaha menengah atau usaha besar yang memenuhi kriteria usaha kecil yang diatur dalam undang-undang.

Usaha Menengah, Seperti yang diatur dalam (Undang-Undang Republik Indonesia Tentang Usaha Mikro, Kecil, Dan Menengah, 2008a) Usaha ekonomi produktif yang berdiri sendiri, yang dilakukan oleh perseorangan atau badan usaha yang bukan merupakan anak perusahaan atau cabang perusahaan yang dimiliki, dikuasai, atau menjadi bagian baik langsung maupun tidak langsung dengan usaha kecil atau usaha besar dengan jumlah kekayaan bersih atau hasil penjualan tahunan. Adapun kriteria yang digunakan untuk mendefinisikan UMKM seperti yang tercantum (Undang-Undang Republik Indonesia Tentang Usaha Mikro, Kecil, Dan Menengah, 2008b)adalah nilai kekayaan bersih atau nilai aset tidak termasuk tanah dan bangunan tempat usaha, atau hasil penjualan tahunan Dengan kriteria sebagai berikut : (1) Usaha mikro adalah unit usaha yang memiliki aset paling banyak Rp.50 juta tidak termasuk tanah dan bangunan tempat usaha dengan hasil penjualan tahunan paling besar Rp.300 juta. (2) Menurut (Supriyanto Eko, 2019) Usaha kecil dengan nilai aset lebih dari Rp. 50 juta sampai dengan paling banyak Rp.500 juta tidak termasuk tanah dan bangunan tempat usaha memiliki hasil penjualan tahunan lebih dari Rp.300 juta hingga maksimum Rp.2.500.000,00, dan (3) Usaha menengah adalah perusahaan dengan milai kekayaan bersih lebih dari Rp.500 juta hingga paling banyak Rp.100 milyar hasil penjualan tahunan di atasRp.2,5 milyar sampai paling tinggi Rp.50 milyar.

\section{Industri Pariwisata}

Menurut (Instruction of Presidental RI No.9/1969, 1969) Pengertian industri pariwisata akan jelas jika kita belajar dari suatu 
produk yang menghasilkan atau jasa. Industri pariwisata baru dikenal di Indonesia setelah keluarnya sebagai berikut:Dalam Indtruksi presiden deijelaskan bahwa :(Instruction of Presidental RI No.9/1969, 1969) "Usaha-usaha pengembangan pariwisata di Indonesia bersifat suatu pengembangan industri pariwisata dan merupakan bagian dari usaha pembangunan serta kesejahteraan masyarakat dan Negara"

Usaha pembangunan pariwisata di Indonesia merupakan perluasan industri pariwisata dan merupakan bagian dari perluasan dan pengembangan usaha, kesejahteraan rakyat dan negara.

Menurut (M.A. Camilleri, 2018) Fungsi utama industri pariwisata adalah untuk melayani wisatawan. Keberhasilannya bergantung pada hubungan positif antar semua sektor. Sinergi antar penyedia jasa pariwisata ini diharapkan dapat menjadi pengalaman positif bagi para wisatawan secara individu. Pada dasarnya, pariwisata terdiri dari empat sektor utama: (i) Transportasi (ii) Akomodasi (iii) Layanan Pendukung dan (iv) Penjualan dan Distribusi.

Hal ini juga di kemukakan (M.A. Camilleri, 2018) bahwa "Produk pariwisata dapat berupa; pariwisata perkotaan (atau kota), wisata tepi laut, wisata pedesaan, ekowisata, wisata anggur, wisata kuliner, wisata kesehatan, wisata kesehatan, wisata religi, wisata budaya (atau warisan), olah raga, wisata pendidikan, wisata bisnis (termasuk pertemuan, insentif, konferensi dan acara).

Menurut The Association of International Expert and Scientific in Tourism (AIEST) (dalam A.Yoeti, 2005) produk industri pariwisata adalah "The product covers the complete experiences from the time he (tourist) leaves home to the time he returns to it". Hal ini berarti "Produk industri pariwisata merupakan semua bentuk pelayanan yang dinikmati wisatawan semenjak ia berangkat meninggalkan tempat dimana ia biasa tinggal hingga ia kembali pulang".

Menurut Middleton dalam buku Marketing In Travel and Tourism (dalam Yoeti, 2005) memberi batasan produk industri pariwisata yaitu sebagai berikut: (1) "The product may be defined as a bundle or package of tangible and intangible components, based on activity at a destination"; (2) "There are five main components in the total product are: Destination Attraction; Destination Facilities and Services; Accessibilities of The Destination; Image of The Destination; Price to the consumen"

Dari penjelaskan di atas bisa disimpulkan bahwa produk wisata : (1) Produk wisata bisa didefinisikan sebagai bundel atau paket komponen berwujud dan tidak berwujud, berdasarkan aktivitas di tempat tujuan' (2) terdapat lima komponen utama dalam total produk wisata diantaranya : Atraksi Destinasi; Fasilitas dan Layanan Destinasi; Aksesibilitas Destinasi; Gambar Tujuan; Harga untuk Konsumen.

Dimana lima komponen tersebut saling berhubungan satu sama lain demi terciptanya kepuasan dari wisatawan ketika membeli produk di suatu daerah.

menurut (Suwantoro, 2004) mengatakan produk dengan produk wisata ialah produk wisata merupakan suatu produk yang nyata, produk ini merupakan suatu rangkaian jasa yang tidak hanya mempunyai segi-segi yang bersifat ekonomis, tetapi juga yang bersifat social, psikologis dan alam, walaupun produk wisata itu sendiri sebagian besar dipengaruhi oleh tingkah laku ekonomi. Adapun ciri-ciri produk wisata yaitu:

Hasil atau produk wisata tidak dapat dipindahkan. Karena itu dalam penjualannya tidak mungkin produk itu dibawa kepada konsumen. Sebaliknya, konsumen (wisatawan) yang harus dibawa ketempat dimana produk itu dihasilkan. Hal ini berlainan dengan industri barang dimana hasil atau produknya dapat dipindahkan kemana barang tersebut di perlukan oleh konsumen.

Produksi dan konsumsi terjadi pada tempat dan saat yang sama. Tanpa adanya konsumen yang membeli produk atau jasa maka tidak akan terjadi proses produksi.

Produk wisata tidak menggunakan standar ukuran fisik tetapi menggunakan standar pelayanan yang didasarkan atas suatu kriteria tertentu.

Konsumen tidak dapat mencicipi atau mencoba contoh produk itu sebelumnya, bahkan tidak dapat mengetahui atau menguji produk itu sebelumnya.

Hasil atau produk wisata itu banyak tergantung pada tenaga manusia dan hanya sedikit yang mempergunakan mesin. f. Produk wisata merupakan usaha yang mengandung resiko besar.

\section{Pademi Covid -19}

Seperti yang disinyalir dalam berita menurut (Widyaningrum, 2020) "Pademi 
Covid 19 Pada 11 Maret 2020 lalu, World Health Organization (WHO) sudah mengumumkan status pandemi global untuk penyakit virus corona 2019 atau yang juga disebut corona virus disease 2019 (COVID19)". Menurut (Dinkes Jabar, 2020) Bahwa “ Baik epidemi maupun pandemi sejatinya punya arti yang serupa, tapi tak sama dengan wabah. Kata wabah sendiri bisa diartikan sebagai melonjaknya jumlah kasus penyakit tertentu di tempat tertentu.Yang membedakan epidemi dan pandemi adalah, kedua kata tersebut memiliki rujukan tentang skala. Karena, kedua kata itu biasanya dipergunakan oleh lembaga yang mengurus kesehatan masyarakat, baik di tingkat negara maupun dunia. Epidemi biasa digunakan untuk menyebut wabah dalam skala yang besar. Sedangkan pandemi biasa digunakan untuk merujuk ke wabah yang memiliki skala global".

\section{E-Commerce jadi solusi buat pelaku Usaha Mikro Kecil dan Menengah dalam memasarkan produk serta mengembangkan industri pariwisata di tengah Pademi Covid-19}

Menurut (Suswanto dan Setiawati, 2020) Bahwa "kurangnya mobilitas massa di sekitar pasar tentu menghambat laju promosi yang berpengaruh kepada tingkat penjualan. Mengatasi hal tersebut, pemasaran secara online melalui media merupakan langkah tepat yang harus dilakukan oleh para pelaku usaha"

Salah satu langkah yang dapat dilakukan oleh pelaku UMKM adalah dengan melakukan optimalisasi digital marketing terutama dalam sektor peningkatan social media marketing, online advertising, video marketing, search engine marketing, dan pengelolaan website. Sehingga digitalisasi pemasaran yang dilakukan UMKM sangatlah tepat dalam meningkatkan penjualan dan online engagement untuk mengembangkan skala usaha di tengah pandemi Covid- 19.

(Nadya, 2016) menjelaskan ketepatan untuk memilih media yang sesuai dengan perkembangan teknologi, sesuai dengan kecenderungan perilaku konsumen dalam media elektronik, dengan sendirinya memberikan opini yang menimbulkan pertimbangan bagi calon konsumen lain untuk melakukan pembelian.

Pandemi Covid-19 membatasi para konsumen untuk membeli produk UMKM secara langsung. Adanya pandemi ini juga menyebabkan banyaknya peraturan yang dikeluarkan oleh pemerintah, seperti larangan untuk berkerumun dan adanya Pemberlakuan Pembatasan Kegiatan Masyarakat (PPKM). Kondisi tersebut menyebabkan para mitra kesulitan dalam melayani konsumen yang biasanya berkumpul di lapak para mitra UMKM.

Melihat pola konsumsi masyarakat yang saat ini berubah, penjualan secara online atau e-commerce sekarang merupakan sebuah solusi bagi UMKM yang pasti bisa menjalankan usahanya, untuk tetap memasarkan produknya sesuai protokol pencegahan covid-19.

Menurut (Bryan A. Garner dalam Barakatullah dkk, 2005) menyatakan bahwa "E-Commerce the practice of buying and selling goods and services trough online consumer services on the Internet. The e, ashortened from electronic, has become a popular prefix for other terms associated with electronic transaction". Hal ini bisa dijelaskan bahwa pengertian e-commerce yang dimaksud adalah pembelian dan penjualan barang dan jasa dengan menggunakan jasa komputer online di Internet.

Menurut Google, Temasek, Bain \& Co, 2019 dalam (Faqir, 2020) bahwa "Saat ini diperkirakan baru ada 8 juta UMKM atau sekitar 4,8 persen yang tergabung dalam platform e-commerce dari total 60 juta UMKM. Padahal menurut hasil survei dari Asosiasi Penyelenggara Jasa Internet Indonesia (2019), jumlah penduduk Indonesia yang sudah mengakses internet mencapai 171 juta tahun lalu. Potensi e-commerce Indonesia sendiri diprediksi mencapai US $\$ 82$ miliar di 2025"

Fasilitas umum yang kebanyakan di kota-kota besar sudah terdapat Wi-Fi. Kondisi ini merupakan peluang bagi pengusaha untuk mengembangkan usahanya melalui teknologi yaitu e-commerce.

Hal ini tentunya sangat berpengaruh pada industri pariwisata yang ada di kota Tasikmalaya, sehingga penggunaan media digital melalui platform e-commerce mengalami perkembangan yang cukup berarti bagi dunia industri ,bisa dilihat di tabel 2 dan 3 di bawah ini.

\section{Kajian Empiris}

Hasil penelitian (Purnamasari, dan Ari Pradhanawati, 2015) Peluang penggunaan ecommerce adalah teknologi yang semakin lama semakin maju dan berkembang dimana 
masyarakat harus segera memanfaatkan kemajuan teknologi ini. Serta kebijakan pemerintah yang sudah ada untuk mengupayakan bawa UKM harus mempergunakan e-commerce dalam pengembangan usaha kecil dan menengah. Dan juga pangsa pasar yang menerima adanya e-commerce terlihat pada konsumen sekarang ini sudah menggunakan gadget dilengkapi dengan mobile data. Strategi bisnis penjualan online dapat sukses jika di dukung oleh kinerja aplikasi E-Commerce yang optimal mulai dari pemesanan barang, pembayaran sampai pengiriman barang harusnya dilakukan dengan cepat, murah, aman, dan nyaman. Kinerja aplikasi E-Commerce juga harus di dukung dengan variatifnya produk yang dijual di toko online, program-program dari pengelola untuk menarik pembeli seperti diskon, reward bagi konsumen tetap, dan lain sebagainya, penjualan online juga dapat berhasil jika kualitas SDM karyawan maupun pengelola situs penjualan online lebih baik sehingga dapat melayani konsumen dengan baik dan menciptakaan kesetiaan pelanggan

Hasil penelitian (Maya, 2016) strategi penjualan melalui e-commerce mengalami peningkatan sebesar 348\% dari tahun 2014 ke tahun 2015. Peningkatan juga terjadi tahun 2015 sampai Juli 2016 sebesar 25\%. Hal yang dilakukan pengusaha melalui e-commerce yaitu pendekatan kepada pelanggan dan memberikan kemudahan dalm melakukan transaksi pembelian. Sektor usaha yang diminati pasar adalah sektor makanan (food), fashion dan rumah tangga. Kesimpulan dari penelitian ini adalah peningkatan penjualan efektif dan efisien dapat dilakukan melalui ecommerce. Adapun saran yang dapat di jalankan agar penjualan Usaha Kecil Menengah semakin baik adalah dengan melakukan inovasi dan kreativitas terhadap produk serta melakukan diverensiasi produk untuk meningkatkan daya saing.

Menurut (Jauhari, 2010) dalam penelitiannya mengatakan bahwa "Penjualan dan pemasaran produk melalui dunia maya mempunyai banyak keuntungan yaitu cakupan yang luas, tidak mengenal ruang dan waktu, dapat dilakukan kapan saja dan dimana saja".

\section{METODE PENELITIAN}

Menurut (Sugiyono, 2017a) bahwa: "Metode penelitian kualitatif sering disebut metode penelitian naturalistik karena penelitiannya dilakukan pada kondisi yang alamiah (natural setting); disebut juga sebagai metode etnographi, karena pada awalnya metode ini lebih banyak digunakan untuk penelitian bidang antropologi budaya; disebut sebagai metode kualitatif, karena data yang terkumpul dan analisisnya lebih bersifat kualitatif".

Menurut (Moleong . Lexy J, 2012) bahwa "metode penelitian kualitatif adalah penelitian yang menghasilkan data deskriptif berupa kata-kata lisan dari orang-orang yang perilakunya dapat diamati oleh peneliti." (Sugiyono, 2017c), mengatakan bahwa "metode penelitian pada dasarnya merupakan cara ilmiah untuk mendapatkan data dengan tujuan dan kegunaan tertentu". Berdasarkan hal tersebut, bisa disimpulkan ada empat kata kunci yang perlu diperhatikan yaitu cara ilmiah, data, tujuan dan kegunaan. Sehingga peneliti memilih menggunakan metode penelitian kualitatif untuk menentukan cara mencari, mengumpulkan, mengolah dan menganalisis data hasil penelitian tersebut. Penelitian yang digunakan yaitu penelitian kualitatif deskriptif. Menurut (Sugiyono, 2017c) bahwa "Penelitian kualitatif deskriptif adalah berupa penelitian dengan metode atau pendekatan studi kasus" (Arikunto, 2006) menyatakan bahwa "penelitian deskriptif adalah penelitian yang tidak bermaksud menguji hipotesis tetapi hanya menggambarkan seperti apa adanya tentang suatu variabel, gejala atau keadaan"

Peneliti menentukan subjek penelitian dengan teknik purposive sampling. Menurut (Sugiyono, 2017c) purposive sampling yaitu teknik pengambilan sampel data yang didasarkan pada pertimbangan tertentu. Sampel yang digunakan dalam hal ini adalah Jenis UMKM yang ada disekitar Kota Tasikmalya sebanyak 10 UMKM. Subjek dan objek penelitian yang telah ditentukan oleh peneliti dapat dilihat berdasarkan tabel 1 .

\section{Rumus Mencari Prosentase:}

$$
P=\frac{f}{n} \times 100
$$

$\mathrm{P}=$ Jumlah dalam presentase

$\mathrm{F}=$ Jumlah dalam sebulan

$\mathrm{n}=$ Jumlah dalam tiga bulan

Sumber : Arikunto (2006:81)

Persentase $=($ Jumlah Bagian $/$ Jumlah Keseluruhan) x $100 \%$ 
Menurut (Sugiyono, 2017c) bahwa "pengumpulan data dapat dilakukan dengan berbagai cara dan sumber. Bila dilihat dari sumber datanya, maka pengumpulan data dapat menggunakan sumber primer dan sumber sekunder. Sumber primer adalah sumber data yang langsung memberikan data kepada pengumpul data, dan sumber sekunder adalah sumber yang tidak langsung memberikan data kepada pengumpul data, misalnya lewat orang lain atau lewat dokumen. Bila dilihat dari segi cara atau teknik pengumpulan data, maka teknik pengumpulan data dapat dilakukan dengan cara wawancara, kuesioner, observasi, dan gabungan ketiganya. "

Menurut Esterberg dalam buku (Sugiyono, 2011a) bahwa" wawancara merupakan pertemuan dua orang untuk bertukar informasi dan ide melalui tanya jawab, sehingga dapat dikonstruksikan makna dalam suatu topik tertentu. Wawancara yang digunakan peneliti adalah wawancara semi terstruktur. Wawancara semi terstruktur sudah termasuk dalam kategori in-depth interview yang pelaksanaannya lebih bebas bila dibandingkan dengan wawancara terstruktur .Estenberg dalam buku (Sugiyono, 2011b) menyatakan bahwa "Tujuan wawancara jenis ini adalah untuk menemukan permasalahan secara lebih terbuka dan pihak yang diajak wawancara ,diminta pendapat dan ideidenya". Dalam melakukan wawancara, peneliti menggunakan media sosial Whatapp dikarenakan situasi pademi covid-19 yang tidak memungkinkan bertemu langsung dengan pemilik UMKM dan orang banyak.

Berikut adalah profil narasumber:
1.Nama Perusahaan
: CV.Cendrawasih
Pemilik
: Ibu Elin
Jenis Usaha
: Makanan ringan
Waktu wawancara
: 8 Januari 2021
Pukul 14.56 s.d 17.00 WIB

2. Nama Perusahaan : :Gudang Kerudung

Pemilik

: Ibu Aisyah

Jenis Usaha

: Kerudung Wanita

Waktu wawancara
:7 Januari 2021
Pukul 08.00 s.d 11.00 WIB

3..Nama Perusahaan :Makaroni Kiwil

Pemilik

Jenis Usaha : : Snack/makaroni

Waktu wawancara : 8 Januari 2021

Pukul 08.00 s.d 11.00

4. Nama Perusahaan :RNF Creation

Pemilik

Jenis Usaha

:Ibu Risma Fauziah

:Kerudung

Waktu wawancara :7 Januari 2021

Pukul 08.00 s.d 11.00 WIB

5.Nama Perusahaan :Sandi Collection

Pemilik

Jenis Usaha

:Bapak Sandi

.7 Januari 2021

Pukul 11.00 s.d 13.00 WIB

6. Nama Perusahaan :Makaroni Bantet Pemilik

:Bapak Aji

Jenis Usaha

:Makaroni

Waktu wawancara :9 Januari 2021

Pukul 09.00 s.d 11.00 WIB

7 .Nama Perusahaan :Arumies Cake

Pemilik

Jenis Usaha

:lbu Meika

:Kue Kering

Waktu wawancara :10 Januari 2021

Pukul 08,00 s.d 11.00 WIB

8. Nama Perusahaan :Pedora

Pemilik

:Bapak Yoga

Jenis Usaha

:Kaos

Waktu wawancara :11 Januari 2021

Pukul 09.00 s.d 11.00 WIB

9. Nama Perusahaan : Destee

Pemilik

: Ibu Hesty

Jenis Usaha : : Baju

Waktu wawancara $\quad$ : 11 Januari 2021

10. Nama Perusahaan: Ochidai

Pemilik : Ibu Yosi

Jenis Usaha : Mini Cupcakes

Waktu wawancara : 11 Januari 2021

Pukul 12.30 s.d 13.,00

Tabel 1. Panduan Wawancara Tentang Penjualan

\begin{tabular}{cl}
\hline NO & \multicolumn{1}{c}{ Aspek yang ditanyakan } \\
\hline 1 & $\begin{array}{l}\text { Berapa potong/pieces/toplos yang terjual di masa Pademi Covid-19 kurun waktu } \\
\text { dimulai }\end{array}$ \\
\hline & Bulan Mei sampai dengan Oktober ? \\
\hline 2 & Apakah menaik atau menurun? \\
\hline 3 & Jenis Usaha Apa yang dikelola ? \\
\hline 4 & Apakah sudah pernak menggunakan media Sosial untuk penjualan ? \\
\hline
\end{tabular}




\begin{abstract}
$5 \quad$ Mengapa beralih penjualanya melalui E-Commerce?
$6 \quad$ Kemudahan apa yang didapatlkan melalui media E-Commerce?

7 Apakah sudah menggunakan media E-Commerce Sebelumnya?

8 Apakah E-Commerce menjadi solusi bagi pelaku UMKM di masa Pademi Covid-19?

Sumber :Data Wawancara (2020)
\end{abstract}

Instrumen penelitian dalam pendekatan kualitatif adalah peneliti sendiri dibantu dengan beberapa alat untuk mengumpulkan data atau informasi yang bermanfaat untuk menjawab permasalahan.Instrumen ini mempermudah peneliti untuk melakukan observasi, wawancara, dan dokumentasi yang disusun dalam bentuk panduan (Sugiyono, 2017b).

Dalam penelitian ini menggunakan dua cara dokumentasi, yaitu: (1) Rekaman Audio; (2) Catatan. Penulis menggunakan dua cara dalam melakukan wawancara yaitu : Komunikasi melalui Whatapp; (2) Catatan.

\section{HASIL DAN PEMBAHASAN}

\section{Hasil Penelitian}

Hasil dari penelitian dan wawancara dengan pemilik UMKM di lingkungan Kota Tasikmalaya bahwasannya penjualannya meningkat dimasa pademi covid-19 mulai bulan September s.d Oktober dapat dilihat di tabel 2 di bawah ini :

Tabel 2. Data UMKM di Lingkungan Kota Tasikmalaya bulan Mei s.d Oktober 2020

\begin{tabular}{|c|l|r|r|r|r|r|r|r|c|c|}
\hline \multirow{2}{*}{ No } & Nama UMKM & \multicolumn{6}{|c|}{ U } & \multicolumn{1}{|c|}{ Q A N } & JENIS USAHA \\
\cline { 3 - 8 } & & Mei & Juni & Juli & Agust & Sep & Oktober & & \\
\hline 1 & CV Cendrawassih & 1,000 & 1,200 & 1,000 & 1,000 & 1,200 & 2,400 & $\mathrm{pcs}$ & makanan ringan \\
\hline 2 & Gudang Kerudung & 500 & 600 & 500 & 500 & 600 & 700 & $\mathrm{pcs}$ & kerudung \\
\hline 3 & Makaroni Kriwil & 200 & 300 & 200 & 200 & 300 & 400 & $\mathrm{pcs}$ & snack/makaroni kriwil \\
\hline 4 & RNF Creation & 718 & 524 & 524 & 500 & 718 & 1,112 & $\mathrm{pcs}$ & kerudung \\
\hline 5 & Sandi Collection & 418 & 418 & 418 & 418 & 655 & 1,375 & $\mathrm{pcs}$ & mukena \\
\hline 6 & Makaroni Bantet & 15,000 & 15,000 & 15,000 & 15,000 & 20,000 & 35,000 & $\mathrm{pcs}$ & snack/makaroni bantet \\
\hline 7 & Arumies Cake & 96 & 147 & 96 & 96 & 147 & 430 & $\mathrm{pcs}$ & Makanan/kue kering \\
\hline 8 & Fedora & 90 & 162 & 90 & 90 & 162 & 170 & $\mathrm{pcs}$ & Kaos \\
\hline 9 & destee & 60 & 65 & 60 & 60 & 65 & 75 & $\mathrm{pcs}$ & baju muslimah \\
\hline 10 & Ochidai mini cupcakes & 150 & 200 & 150 & 150 & 150 & 200 & $\mathrm{pcs}$ & Cup cake \\
\hline
\end{tabular}

Sumber : Hasil Wawancara (2020)

Dengan menggunakan rumus presentase kita yang terjual dimasa pademi covid -19, dapat bisa melihat berapa presentase (\%) produk terlihat di tabel 3 dibawah ini :

Tabel 3. Data UMKM di Lingkungan Kota Tasikmalaya bulan Mei sd Oktober 2020

\begin{tabular}{|c|c|c|c|c|c|c|c|c|c|c|}
\hline JENIS USAHA & Nama UMKM & Jumlah & & & BULAN & & & & Presentase & Jenis \\
\hline & & Keseluruhan & Mei & Juni & Juli & Agust & Sep & okt & & Usaha \\
\hline makanan ringan & CV Cendrawassih & 7,800 & 12.8 & 15.4 & 12.8 & 12.8 & 15.4 & 30.8 & $\%$ & makanan ringan \\
\hline kerudung & Gudang Kerudung & 3,400 & 14.7 & 17.6 & 14.7 & 14.7 & 17.7 & 20.6 & $\%$ & kerudung \\
\hline snack/makaroni kriwil & Makaroni Kriwil & 1,600 & 12.5 & 18.8 & 12.5 & 12.5 & 18.8 & 25.0 & $\%$ & snack/makaroni kriwil \\
\hline kerudung & RNF Creation & 4,096 & 17.5 & 12.8 & 12.8 & 12.2 & 17.5 & 27.1 & $\%$ & kerudung \\
\hline mukena & Sandi Collection & 3,702 & 11.3 & 11.3 & 11.3 & 11.3 & 17.7 & 37.1 & $\%$ & mukena \\
\hline snack/makaronibantet & Makaroni Bantet & 115,000 & 13.0 & 13.4 & 13.4 & 13.4 & 17.4 & 30.4 & $\%$ & snack/makaroni bantet \\
\hline Makanan/kue kering & Arumies Cake & 1,012 & 9.5 & 14.5 & 9.5 & 9.5 & 14.5 & 42.5 & $\%$ & Makanan/kue kering \\
\hline Kaos & Fedora & 764 & 11.8 & 21.2 & 11.8 & 11.8 & 21.2 & 22.3 & $\%$ & Kaos \\
\hline baju muslimah & Destee & 385 & 15.6 & 16.9 & 15.6 & 15.6 & 16.9 & 19.5 & $\%$ & baju muslimah \\
\hline Cup cake & Ochidai mini cupcakes & 1,000 & 15.0 & 20.0 & 15.0 & 15.0 & 15.0 & 20.0 & $\%$ & Cup cake \\
\hline
\end{tabular}

Sumber : Hasil wawancara tahun 2020 
Website e-commerce telah memberikan manfaat dan kemudahan para pengusaha UMKM untuk memasarkan produk-produknya sehingga pembeli dengan mudah dapat memperoleh informasi produk yang dijual. Website e-commerce juga memberikan kemudahan kepada pembeli dan pengusaha untuk melakukan transaksi, (Darmawan Irfan, Andreswari, 2019). Dan hal ini tentunya mendorong industri pariwisata di kota Tasikmalaya.

\section{Pembahasan}

Berdasarkan hasil wawancara dan penghitungan diatas bahwa penjualan dari setiap UMKM meningkat walaupun dimasa pademi covid-19, dapat dilihat meningkat dibulan Juni $11,3 \%$ sd $21,2 \%$,rata-rata menurun di bulan Juli sd Agustus 9,5\% s.d $15,6 \%$ dari bulan September ke Oktober dan rata- rata naiknya diangka $15 \%$ sd $42,5 \%$.

Penggunaan sistem perdagangan elektronik atau e-commerce sebagai solusi bagi pelaku Usaha Mikro Kecil Menengah (UMKM) dalam memasarkan produknya di tengan Pandemi COVID-19. Sangat bagus dan cerdas karena masyarakat mengalami perubahan pola konsumsi yang awalnya offline sekarang menjadi online. Bahkan diprediksi bahwa "stay at home economy akan menjadi tren di masa yang akan datang," jelas Teten dalam keterangan resmi di Media Center Gugus Tugas Percepatan Penanganan COVID-19, Graha Badan Nasional Penanggulangan Bencana (BNPB), (Tim Komunikasi Publik GT Nasional, 2020).

Hal ini merupakan indikasi bilamana pelaku UMKM memiliki kesempatan dalam meningkatkan usahanya melalui sistem perdagangan elektronik sehingga pandemi Covid-19 bukan halangan untuk melakukan penjualan , akan tetapi justru menjadi momentum yang bagus bagi mereka untuk membuktikan bahwa produk-produk dalam negeri dan kebutuhan masyarakat dapat dipenuhi.Dan hal ini juga sangat mendorong bagi pelaku UMKM dalam mengembangkan industri kreatif dalam menunjang pendapatan kepariwisataan yang terpuruk akibat pademi covid 19 di Tasikmalaya.Menurut (Mulyani, 2018) "Dimana makanan olahan atau kuliner termasuk no 15 sektor terakhir adalah industri kuliner. Industri kuliner kian menggeliat di Indonesia. Data dari Badan Ekonomi Kreatif (Bekraf) Republik Indonesia mencatat, subsektor kuliner berkontribusi 41,4 persen dari total kontribusi perekonomian kreatif $\mathrm{Rp}$ 922 triliun pada 2016. Jumlah tersebut merupakan yang paling tinggi dibandingkan 16 subsektor lain di Bekraf Rl". Seperti yang disinyalir dalam laman website nya kemenkraf (Kreatif \& Indonesia, 2019) Bahwa "Sub sektor kuliner memberikan kontribusi yang cukup besar, yaitu $30 \%$ dari total pendapatan sektor pariwisata dan ekonomi kreatif. Industri kuliner mempunyai potensi yang sangat kuat untuk berkembang, oleh karena itu pemerintah akan mendukung sub sektor ini supaya lebih maju"

\section{PENUTUP}

Dengan memanfaatkan E-Commerce dalam operasional bisnisnya, UMKM akan mendapatkan akses pasar yang lebih luas dan berpeluang menggaet pelanggan baru. Di sisi lain, pelanggan akan lebih mudah mendapatkan informasi yang diperlukan secara on-line. Berbagai penghematan dan efisiensi akan dicapai seperti dalam hal biaya, pengiriman, komunikasi telepon atau fax, dokumen, transportasi cetakan, waktu dan tenaga kerja. Sehingga pengusaha UMKM akan tetap bertahan di masa pademi covid 19 dengan memanfaatkan teknologi melalui perdagangan elektronik atau e-commorce karena hal ini merupakan solusi bagi mereka para pengusaha dan pembeli di situasi social distancing, stay at home dan work from home.

Perkembangan bisnis kuliner yang sangat cepat juga terjadi di Kota Tasikmalaya. Industri di kota Tasikmalaya terus menggeliat, hal tersebut terbukti dengan banyaknya usahausaha kuliner baru yang hadir di kota Tasikmalaya.Menggeliatnya industri kuliner itulah yang menjadikan potensi untuk terus dikembangkan dan menjadi sektor perekonomian unggulan di kota Tasikmalaya. dalam acara Bimbingan Teknis pengembangan Destinasi Wisata Kuliner Kota Tasikmalaya yang digelar di Ballroom Hotel Horison Tasikmalaya serperti yang diutarakan oleh Deputi Bidang Pengembangan Destinasi Pariwisata RI Dadang Rizki Ratman bahwa “ tujuan digelarnya Bimtek adalah untuk memberikan spirit kepada para penggiat kuliner di Kota Tasikmalaya untuk terus mengembangkan wisata kuliner sehingga dapat menjadi sektor wisata andalan kota Tasikmalaya."(Aditia, 2018).

Menurut Kepala dinas kebudayaan, pariwisata, pemuda dan olahraga kota Tasikmalaya H.Undang Hendyana menuturkan 
bahwa " Kulliner di kota Tasikmalaya sudah memenuhi unsur sapta pesona sehingga di harapkan bisa disentralisasi dengan tempat yang strategis,aman dan higinies ,supaya wisatawan bisa berkujung ke pusat wisata kuiner di kota Tasikmalaya dan wisatawan nyaman serta tertarik untuk datang lagi"(Aditia, 2018). Kita bisa lihat kenaikan permintaan masyarakat atau pengujung untuk makanan olahan dan produk umkm cukup meningkat di bulan oktober mulai dari $19,5 \%$ sampai dengan $42,5 \%$ bisa kita lihat ditabel 3

Salah satu bukti pesatnya perkembangan TIK adalah kehadiran internet sebagai media komunikasi yang menjadi kebutuhan dan tidak dapat dipisahkan dari kehidupan masyarakat modern saat ini. Internet telah menghantarkan kita memasuki era e-commerce yang serba digital. Bahkan saat ini, kita sudah berada di era revolusi industri 4.0. Revolusi industri 4.0 ini akan memberikan efek memperdekat jarak antara produsen dan target market-nya. (Bessie, 2019) Dalam penelitian ini masih terdapat kekurangan mengenai jumlah wisatawan yang belanja makanan kuliner atau lahan yang ada di Tasikmalaya,Diharapkan untuk peneliti selanjutnya bisa mendapatkan angka jumlah wisatawan yang datang ke Tasikmalaya.

\section{DAFTAR PUSTAKA}

A.Yoeti, O. (2005). Perencanaan Strategi Pemasaran Daerah Tujuan Wisata. PT. Pradnya Paramita.

Faqir, Anisyah Al. (2020). Jualan di Tengah Pandemi, UMKM Diminta Manfaatkan ECommerce. Website Online, 2. www.liputan6.com

Arikunto. (2006). Metode Penelitian Kualitatif (p. 291). Bumi Aksara.

Bryan A. Garner dalam Abdul Halim Barakatullah dkk. (2005). Konsep belanja ECommerce (p. 12).

Aditia, Clara. (2018). Geliat industri kuliner kota Tasikmalaya jadi potensi. Trend .Koropak.Co.ld.

Irfan, Darmawan dan Andreswari, P. W. (2019). Pemanfaatan E-Commerce Dalam Peningkatan Pemasaran di UMKM Grosir Batik Tasikmalaya. Charity Jurnal Pengabdian Masyarakat, 02(01).

Reswari, Dewi Maharani Indah. (2020, April). Pandemi Corona, Ini 5 Keluhan Para Pelaku Bisnis UMKM. Www.Jurnal.ld. https://www.jurnal.id/id/blog/keluhan- para-pelaku-bisnis-umkm-saat-corona/

Dinkes Jabar. (2020). Buku petunjuk TENTANG NOVEL CORONAVIRUS (NCOV). Dinas kesehatan Jabar.

instruction of Presidental RI No.9/1969, Pub. L. No. 9 (1969).

Widyaningrum, Gita Laras. (2020). WHO Tetapkan COVID-19 Sebagai Pandemi Global, Apa Maksudnya? https://nationalgeographic.grid.id/read/13 2059249/who-tetapkan-covid-19-sebagaipandemi-global-apa-maksudnya

Jauhari, J. (2010). "Upaya Pengembangan Usaha Kecil dan Menengah (UKM) dengan Memanfaatkan E-commers. Jurnal Sistem Informasi UNSRI, 2(1), 271-279.

Wong, Jony. (2010). Internet Marketing for Beginners. PT Elex Media Komputindo.

Bessie, Juita L.D. (2019). IMPLEMENTASI ECOMMERCE DALAM INDUSTRI PARIWISATA. BesSie / JOURNAL OF MANAGEMENT (SME'), 8(1), 45-62.

Kotler, Philip and Armstrong Gary. (2012). Prinsip-prinsip Pemasaran (13 jilid 1). Erlangga.

Kotler, Philip and Armstrong Gary. (2016). Principles of Marketing (16th ed.). Pearson Education Limited.

Kreatif, logo-kemenparekrafKementerian $P$. dan E. K. / B. P. dan E., \& Indonesia, R. (2019). Subsektor Ekonomi Kreatif. Https://Kemenparekraf.Go.Id/Layanan/Su bsektor-Ekonomi-Kreatif.

https://kemenparekraf.go.id/layanan/Subs ektor-Ekonomi-Kreatif/Kuliner

M.A. Camilleri. (2018). Travel Marketing, Tourism Economics and the Airline Product, Tourism, Hospitality \& Event Management,. Springer International Publishing, 3-27.

Dinisari, Mia Chitra. (2010, April 17). Ecommerce Dorong Perekonomian Indonesia, selama Pandemi Covid-19. Bisnis.Com.

https://ekonomi.bisnis.com/read/2020041

7/12/1228750/e-commerce-dorongperekonomian-indonesia-selamapandemi-covid-19-

Moleong . Lexy J. (2012). Metodologi Penelitian Kualitatif (p. 4). PT Remaja Rosdakarya.

Nadya. (2016). Peran Digital Marketing dalam Eksisten Bisnis Kuiner Seblak Jeletet Murni. Jurnal Riset Manajemen Dan Bisnis, 1(2), 133-144. 
UNDANG-UNDANG REPUBLIK INDONESIA TENTANG USAHA MIKRO, KECIL, DAN MENENGAH, (2008).

https://www.ojk.go.id/sustainable-

finance/id/peraturan/undangundang/Documents/Undang-Undang

Nomor 20 Tahun 2008 Tentang Usaha Mikro, Kecil, dan Menengah.pdf

UNDANG-UNDANG REPUBLIK INDONESIA TENTANG USAHA MIKRO, KECIL, DAN MENENGAH, (2008).

https://www.ojk.go.id/sustainable-

finance/id/peraturan/undang-

undang/Documents/Undang-Undang

Nomor 20 Tahun 2008 Tentang Usaha Mikro, Kecil, dan Menengah.pdf

Putri, S. G. (2020, March 11). WHO Resmi Sebut Virus Corona Covid-19 sebagai Pandemi Global. Kompas Newspaper Online.

https://www.kompas.com/sains/read/202 0/03/12/083129823/who-resmi-sebutvirus-corona-covid-19-sebagai-pandemiglobal

Maya, Siska. (2016). STRATEGI PENINGKATAN PENJUALAN USAHA KECIL MENEGAH MELALUI ECOMMERCE Studi Kasus: Mitra UKM Perusahaan X. Journal of Applied Business and Economics, 2(3), 271-279. https://journal.Ippmunindra.ac.id/

Sugiyono. (2011a). Metode Penelitian Kualitatif,Kuantitatif, $\quad R \& D \quad$ (p. 231). Alfabeta Bandung.

Sugiyono. (2011b). Metode Penelitian Kualitatif,Kuantitatif,R\&D (pp. 233-234). Alfabeta Bandung.

Sugiyono. (2017a). metode penelitian Kualitatif, Kuantitatif, $R \& D$ (p. 8). Alfabeta Bandung.

Sugiyono. (2017b). Metode Penelitian Kualitatif, Kuantitatif, $R \& D \quad$ (p. 102). Alfabeta Bandung.

Sugiyono. (2017c). metode penelitian Metode Penelitian Kuantitatif, Kualitatif, dan R\&D. (p. 8). CV alfabeta.
Supriyanto Eko, M. M. (2019). Pengaruh Usaha Mikro, Kecil dan Menengah (UMKM) Perempuan terhadap Kesejahteraan Masyarakat. Optimal Jurnal Ekonomi Dan Kewirausahaan, 13(21).

Suswanto, P dan Setiawati,S. D. (2020). Membangun Strategi Komunikasi Pemasaran dalam Membangun Positioning di Tengah Pandemi Covid-19 di Indonesia. Lini Masa: Jurnal IImu Komunikasi, 3(2), 16-29.

Suwantoro, G. (2004). Dasar-dasar Pariwisata. Penerbit Andi.

Tim Komunikasi Publik GT Nasional. (2020, April 28). Sistem E-Commerce Jadi Solusi Bagi Pelaku UMKM di Tengah Pandemi COVID-19. Covid19.Go.ld. https://covid19.go.id/p/berita/sistem-ecommerce-jadi-solusi-bagi-pelaku-umkmdi-tengah-pandemi-covid-19

Mulyani, Yani Sri. (2018). Tasikmalaya Oktober Festival sebagai Pembuktian Destinasi Wisata Industri Kreatif dalam Memasarkan Produk Unggulan ke Mancanegara. Jurnal Khasanah IImu, 9(2).

Purnamasari, Yunita dan Ari Pradhanawati W. H. (2015). ANALISIS PELUANG ECOMMERCE DALAM PENGEMBANGAN USAHA MIKRO, KECIL, DAN MENENGAH PRODUK BATIK. Jurnal IImu Administrasi Bisnis, 4(4), 42-49. https://ejournal3.undip.ac.id/index.php/jia b/article/view/9226 